\title{
Assessing the feasibility of applying Reverse Osmosis technology at MN Port
}

\author{
Syaifulloh Hananta ${ }^{1, *}$, Santoso $^{2}$ \\ ${ }^{1}$ Environmental Department, Sucofindo \\ ${ }^{2}$ Bogor Agricultural University
}

\begin{abstract}
This paper aims to assess the feasibility of applying Reverse Osmosis (RO) technology at MN Port. Hydro-oceanography analysis was performed to understand sea conditions in the proximity of MN Port and to determine water intake point. Furthermore, design analysis was also conducted to determine the most suitable RO design to be applied. Based on the hydro-oceanography analysis, the study area is generally shallow water areas with the depth ranges from 2-10 meters, and the type of tide is diurnal tide. The speed and direction of ocean currents range from $0.01-0.06 \mathrm{~m} / \mathrm{s}$ with the dominant direction trending northeast and north. Based on the port development plan and hydro-oceanography analysis, it is recommended that the water intake point is at the north of the port. The results obtained from several analyses show that RO technology can be applied at MN Port.
\end{abstract}

\section{General description of MN Port}

Provision of clean water that is sufficient in quantity, acceptable, and sustainable is one of the vital aspects in supporting operational activities in a port, including $\mathrm{MN}$ Port.

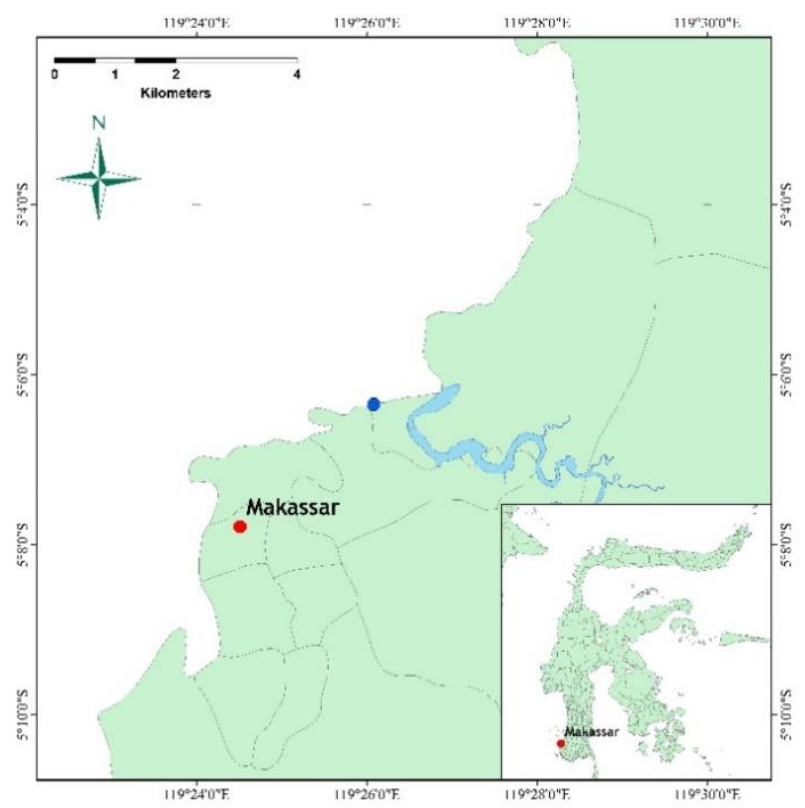

Fig. 1. MN Port location (blue dot).

MN Port is a new port in Makassar City, South Sulawesi Province. Geographically, MN Port is located at $119^{\circ} 26^{\prime} 30^{\prime \prime}$ East and $05^{\circ} 06^{\prime} 45^{\prime \prime}$ South (Figure 1).

In international shipping lanes, the location of $\mathrm{MN}$ Port is very strategic. The port which will have integrated transportation routes is located on the shipping lines of the
Australian Indonesia Development Area (AIDA), Brunei, Indonesia, Malaysia, the Philippine East Asian Growth Area (BIMP EAGA), and Asia Pacific route.

The development of MN Port is divided into several stages (Figure 2), with Phase 1A starting in 2015 and Phase II (final phase) is targeted to be completed in 2032. In line with the port development plan, seawater desalination facility is planned to be built to meet the needs of clean water for port operations, which is estimated around $900 \mathrm{~m}^{3} /$ day.

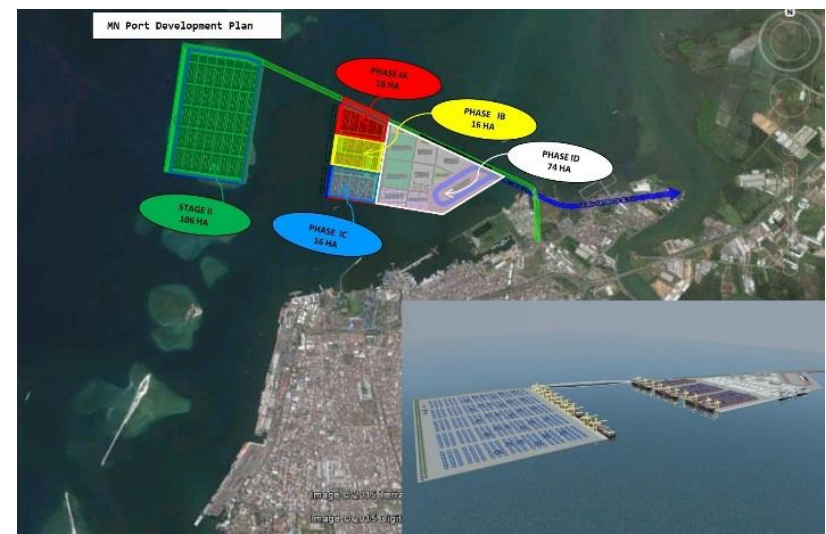

Fig. 2. MN Port development plan.

\section{Hydro-oceanography analysis}

\subsection{Bathymetry}

MN Port is located on the coastal areas of Makassar City which is directly connected to Makassar Strait. The depth

Corresponding author: hanantasyaifulloh@gmail.com 
of the water around the port is shown in Figure 3, depicted in the contour line (iso-depth).

This data is compiled and extracted from the Marine Research Centre, Indonesian Ministry of Marine Affairs and Fisheries [1].

Generally, the depth of the water around $\mathrm{MN}$ port is classified as shallow waters. Water depth on the west side of the port ranges from 6-8 meters, while on the north and the south sides range from 2 to 6 meters.

Based on the development plan of MN Port, In Phase $1 \mathrm{~A}$, dredging projects are carried out to increase the depth of the pier or the west side of the port to 16 meters.

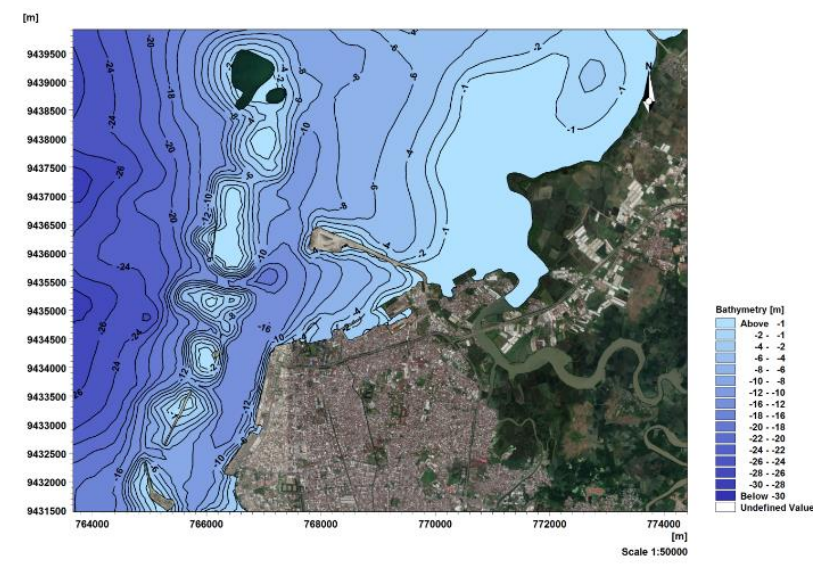

Fig. 3. Water depth map around MN Port.

\subsection{Tide}

Tide data in the study area was obtained from the Indonesian Navy Hydrographic and Oceanographic Centre at Makassar station [2]. This data represents tide conditions for the period of 1-31 August 2018 with 1-hour data interval. Furthermore, with admiralty method tide data was analysed to obtain tide constant shown in Table 1 .

Table 1. Tide constants based on Admiralty analysis.

\begin{tabular}{|l|c|c|}
\hline \multicolumn{1}{|c|}{ Tide Constant } & Amplitude (cm) & Phase Difference \\
\hline M2 & 8 & 63 \\
\hline S2 & 11 & 195 \\
\hline K1 & 28 & 301 \\
\hline O1 & 17 & 270 \\
\hline P1 & 11 & 296 \\
\hline N2 & - & - \\
\hline K2 & 5 & 235 \\
\hline M4 & - & - \\
\hline MS4 & - & - \\
\hline Z0 & \multicolumn{2}{|c|}{80} \\
\hline
\end{tabular}

Based on Table 1, the sum of $\mathrm{K} 1$ and $\mathrm{O} 1$ is more dominant compared to other components. Since K1 and O1 are diurnal tide components (single tide), thus the study area is dominated by diurnal tide.

Quantitatively, the type of tide in the study area is determined by calculating the ratio between the amplitude of single tide elements $(\mathrm{K} 1+\mathrm{O} 1)$ and the amplitude of double tide elements (M2 $+\mathrm{S} 2)$ otherwise known as Formzahl (Fz) number [3].

$$
\mathrm{FZ}=\frac{(K 1+O 1)}{(M 2+O 2)}
$$

Where,
$\mathrm{Fz}<0.25$
: Semi-diurnal
$0.25<\mathrm{Fz}<1.5 \quad$ : Mixed semi-diurnal dominant
$1.5<\mathrm{Fz}<3.0 \quad$ : Mixed diurnal dominant
$\mathrm{Fz}>3.0 \quad$ : Diurnal

From the calculation, a value of 2.37 is obtained. In the courtier criterion, this value falls into mixed mainly diurnal tides. Typically, these tides occur once a day with two times high tides and two times low tides.

Tide data then were visualised in graphic series to clarify the type of tides (Figure 4). From this figure, it can be observed that tide fluctuations occur twice a day, high tide and low tide. However, one of the amplitude looks small and sometimes invisible. This small amplitude only appears when neap tide, while at spring tide the amplitude appears with quite high values.

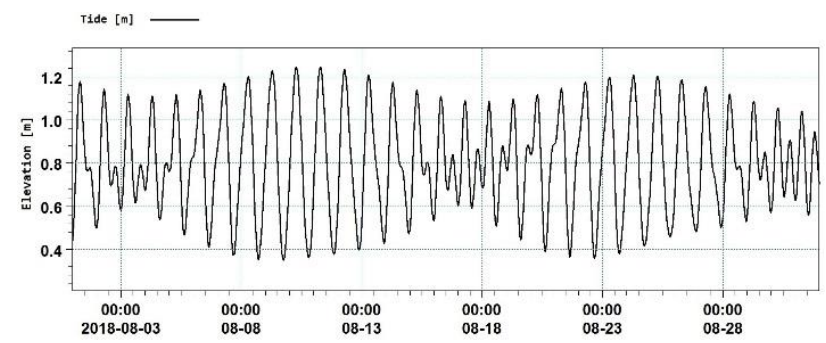

Fig. 4. Tide fluctuations from August 2018 forecast.

Table 2. Tide elevations based on several design water levels and references for mixed mainly diurnal tides.

\begin{tabular}{|l|l|l|c|c|}
\hline \multirow{2}{*}{ Design water level } & \multirow{2}{*}{ Symbol } & \multicolumn{1}{c|}{ Calculation } & \multicolumn{2}{c|}{ Reference } \\
\cline { 4 - 6 } & & & LAT $(\mathrm{m})$ & MSL $(\mathrm{m})$ \\
\hline Highest Astronomical Tide & HAT & $\mathrm{Z}_{0}+($ all constituents $)$ & 1.60 & 0.80 \\
\hline Higher High Water Level & $\mathrm{HHWL}$ & $\mathrm{Z}_{0}+\left(\mathrm{M}_{2}+\mathrm{S}_{2}+\mathrm{K}_{2}+\mathrm{K}_{1}+\mathrm{O}_{1}+\mathrm{P}_{1}\right)$ & 1.60 & 0.80 \\
\hline High Water Spring & $\mathrm{HWS}$ & $\mathrm{Z}_{0}+\left(\mathrm{M}_{2}+\mathrm{S}_{2}+\mathrm{K}_{1}+\mathrm{O}_{1}\right)$ & 1.44 & 0.60 \\
\hline Mean High Water Spring & $\mathrm{MHWS}$ & $\mathrm{Z}_{0}+\left(\mathrm{M}_{2}+\mathrm{S}_{2}\right)$ or $\mathrm{Z}_{0}+\left(\mathrm{K}_{1}+\mathrm{O}_{1}\right)$ & 1.25 & 0.50 \\
\hline Mean High Water Level & $\mathrm{MHWL}$ & $\mathrm{Z}_{0}+\left(\mathrm{M}_{2}+\mathrm{K}_{1}+\mathrm{O}_{1}\right)$ & 1.33 & 0.50 \\
\hline Mean Sea Level & $\mathrm{MSL}$ & $\mathrm{Z}_{0}$ & 0.80 & 0.00 \\
\hline Mean Low Water Level & $\mathrm{MLWL}$ & $\mathrm{Z}_{0}-\left(\mathrm{M}_{2}+\mathrm{K}_{1}+\mathrm{O}_{1}\right)$ & 0.27 & -0.50 \\
\hline Mean Low Water Spring & $\mathrm{MLWS}$ & $\mathrm{Z}_{0}-\left(\mathrm{M}_{2}+\mathrm{S}_{2}\right)$ or $\mathrm{Z}_{0}-\left(\mathrm{K}_{1}+\mathrm{O}_{1}\right)$ & 0.35 & -0.50 \\
\hline Chart Datum Level & $\mathrm{CDL}$ & $\mathrm{Z}_{0}-\left(\mathrm{M}_{2}+\mathrm{S}_{2}+\mathrm{K}_{1}+\mathrm{O}_{1}\right)$ & 0.16 & -0.60 \\
\hline Lower Low Water Level & LLWL & $\mathrm{Z}_{0}-\left(\mathrm{M}_{2}+\mathrm{S}_{2}+\mathrm{K}_{2}+\mathrm{K}_{1}+\mathrm{O}_{1}+\mathrm{P}_{1}\right)$ & 0.00 & -0.80 \\
\hline Lowest Astronomical Tide & LAT & $\mathrm{Z}_{0}-($ all constituents $)$ & 0.00 & -0.80 \\
\hline
\end{tabular}

Based on the constants that have been obtained, the tide elevation then can be determined using several equations as shown in Table 2. In this study, MSL was determined to equal to 0 .

Tide ranges are based on Mean Sea Level (MSL) and Lowest Astronomical Tide (LAT). For spring tide, the heights of the water (MHWS) are 1.25 meters (LAT) and 0.5 meters (MSL) (high tides), while when low tides, the heights of the water (MLWS) are 0.35 meters (LAT) and 0.5 meters (MSL).

The value of tide range or the distance between the highest and the lowest tide based on the overall components is 1.6 meters.

\subsection{Currents}

Sea current data was obtained from hydrodynamic modelling using tides as boundary condition and wind as 
driving force. A model was simulated in January (represent the west season) and July (represent the east season). The duration of the simulation was 15 days to obtain the influences of spring tide and neap tide. Furthermore, the purpose of this hydrodynamic modelling is to obtain a comprehensive overview of sea current characteristics in the study area, spatially and temporally.

The output of the hydrodynamic model has been tested and verified with the aim to determine the accuracy of the model. This verification was done by comparing the simulation results with measurement results. Hydrodynamics component that has been verified is tide.

Based on Figure 5, between the hydrodynamic model and tide data show a similar pattern. It means that the model that has been simulated is accurate.

The results of hydrodynamic simulation have been averaged to obtain residual currents from 15 days of simulation (Figure 6) (Figure 7). The direction and speed of residual currents or average flow do not show a significant difference between west and east season models.

The dominant current directions in the study area are trending northeast to north. In the proximity of the planned site for seawater desalination, the direction of ocean currents is moving away from the beach (to the west, then turn to the northeast). Furthermore, the velocity of the currents around the project location range from $0.01 \mathrm{~m} / \mathrm{s}$ to $0.06 \mathrm{~m} / \mathrm{s}$.

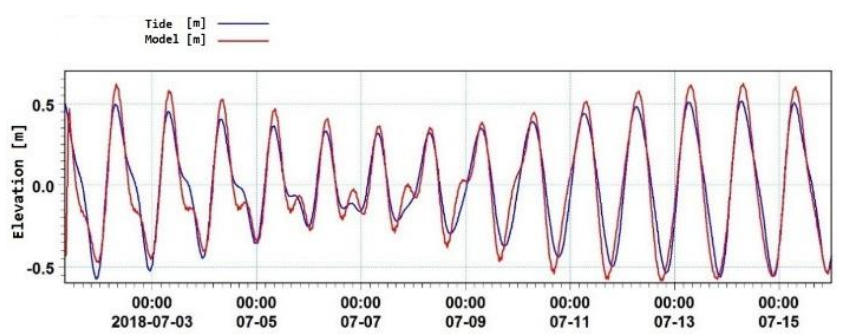

Fig. 5. Comparison between the hydrodynamic model and tide data.

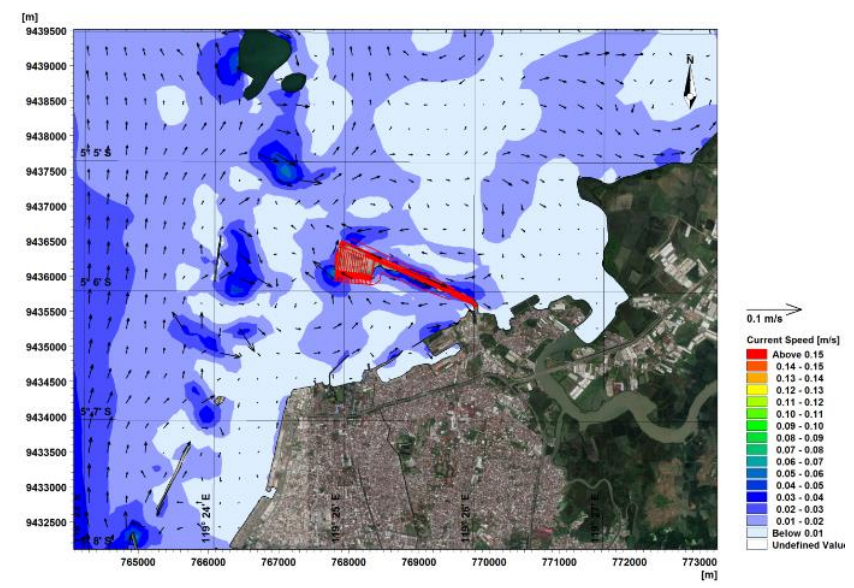

Fig. 6. Residual currents from 15 days of simulation (west season).

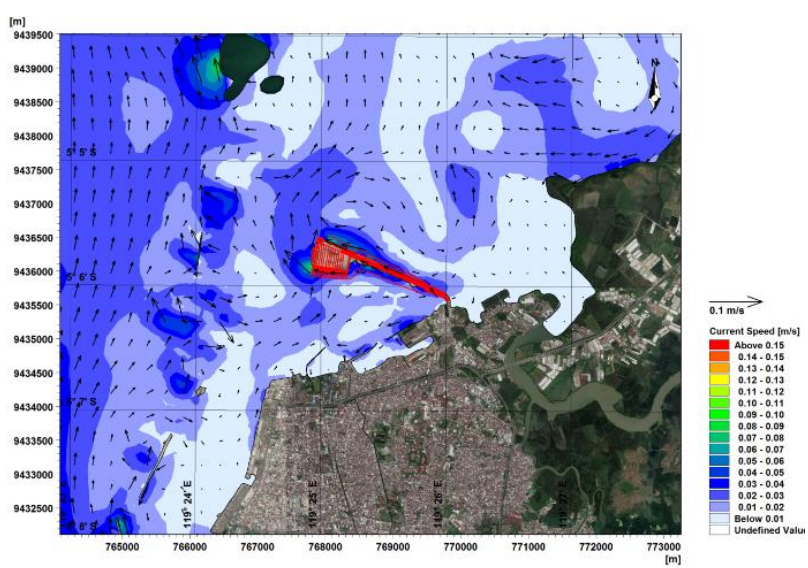

Fig. 7. Residual currents from 15 days of simulation (east season).

\section{Reverse osmosis}

Reverse osmosis is a process that involves greater pressure than osmosis [4] [5]. Unlike osmosis, this highpressure process makes a solution move from higher concentration solution to lower concentration solution.

The basic principle of reverse osmosis is to eliminate dissolved solids, minerals, dissolved and non-dissolved organic matter, aquatic microorganisms, and contaminants in feed water through semipermeable membrane [6] [7]. Reverse osmosis can be applied to desalinate seawater. Sea Water Reverse Osmosis (SWRO) will have two types of output water: fresh water, which then can be given further treatment to become drinking water, and brine.

The screening processes by reverse osmosis selective membrane occur based on the size of the molecule and its charge [6]. The impurities contained in feed water will be repelled, they cannot penetrate the membrane due to their size and molecular weight that is too large and their charge that is not suitable. The rejection rate of dissolved salt, particles, colloids, and bacteria by reverse osmosis membrane can reach up to 95-99 per cent [8] [9].

Reverse osmosis is the most widely used technology in seawater desalination processes. Recorded in 2012, the number of uses of one of these membrane-based technologies reached 63 per cent of total production capacity worldwide [10]. The applications of this technology are projected to continue to increase and achieve a cumulative production capacity of around 80 million $\mathrm{m}^{3} /$ day in 2020 from all reverse osmosis installations worldwide [11].

One of the main problems in processing sea water into clean water using membrane is membrane fouling [12]. Membrane damages can occur on the surface or inside the pores. Moreover, this membrane damage can have an impact on [9]:

- Increase energy consumption

- Shorten membrane life

- Reduce membrane ability to filter certain substances, such as salt, contaminants, etc.

- Reduce the amount of clean water production. 
Based on its causes, membrane damage can be classified into four types: biofouling, organic fouling, scaling, and colloidal fouling [12] [13].

Biofouling occurs due to biofilms that are formed on the surface of the membrane. The formation of these biofilms can have an impact on decreasing water permeation through membrane [12]. Thus, reducing the amount of feed water that can be converted into clean water. Biofouling occurs due to microbiological contamination, such as algae, which is carried by feed water [12].

Organic fouling occurs due to substrates such as hydrocarbons which can coat membrane surface or membrane pore [12]. The clogged pore can reduce the flow of feed water that passes through the membrane.

Scaling is membrane damage due to the deposition of salt on the surface of the membrane [12]. Scaling usually occurs if the feed water has very high salinity. Therefore, it is necessary to control the salinity of the feed water through pre-treatment processes.

Colloidal fouling comes from particles, such as silica or clay, which accumulate on the surface of the membrane [12] [13]. Membrane damage can be controlled by adding anti-scaling agents, disinfectants, and other preliminary processing steps [13].

\subsection{Sea Water Analysis Results}

Pre-treatment stages are vital stages in SWRO processes. It is because the quality of seawater is not always ideal or not recommended for further processing through SWRO membrane.

Given the sensitive characteristics of the membrane, sea water quality must be monitored and controlled. Thus, membrane damage can be minimised. Some parameters that need to be considered along with their recommended values, such as (Table 3) [14] [15] [16] [17]:

Table 3. Parameters to be considered with their recommended values [14] [15] [16] [17]

\begin{tabular}{|c|c|c|}
\hline Parameter & Unit & $\begin{array}{c}\text { Raw/Feed Water } \\
\text { (typical) }\end{array}$ \\
\hline Aluminium $\left(\mathrm{Al}^{3+}\right)$ & $\mathrm{mg} / \mathrm{L}$ & $\leq 0.05$ \\
\hline $\begin{array}{lll}\begin{array}{l}\text { Biological } \\
\text { (BOD) }\end{array} & \text { Oxygen } & \text { Demand } \\
\end{array}$ & $\mathrm{mg} / \mathrm{L}$ & $<5$ \\
\hline Calcium Carbonate $\left(\mathrm{CaCO}_{3}\right)$ & $\mathrm{mg} / \mathrm{L}$ & $\leq 5$ \\
\hline Chlorine $(\mathrm{Cl})$ & $\mathrm{mg} / \mathrm{L}$ & 0.1 \\
\hline Chemical Oxygen Demand (COD) & $\mathrm{mg} / \mathrm{L}$ & $<8$ \\
\hline $\mathrm{Fe}$ & $\mathrm{mg} / \mathrm{L}$ & $\leq 5$ \\
\hline Langelier Saturation Index (LSI) & - & -0.2 \\
\hline Mangan $\left(\mathrm{Mn}^{2+}\right)$ & $\mathrm{mg} / \mathrm{L}$ & $\leq 0.05$ \\
\hline Nitrate $\left(\mathrm{NO}_{3}{ }^{-}\right)$ & $\mathrm{mg} / \mathrm{L}$ & 40 \\
\hline Particle Size & $\mu \mathrm{m}$ & $95 \%>10,5 \%>1$ \\
\hline $\mathrm{pH}$ & - & $5.8-8.6$ \\
\hline Silica $\left(\mathrm{SiO}_{2}\right)$ & $\mathrm{mg} / \mathrm{L}$ & $<20$ \\
\hline Strontium $\left(\mathrm{Sr}^{2+}\right)$ & $\mathrm{mg} / \mathrm{L}$ & $<0.01$ \\
\hline
\end{tabular}

\begin{tabular}{|l|l|r|}
\hline Temperature & ${ }^{\circ} \mathrm{C}$ & $15-35$ \\
\hline Total Dissolved Solids (TDS) & $\mathrm{mg} / \mathrm{L}$ & $\leq 40000$ \\
\hline Total Suspended Solids (TSS) & $\mathrm{mg} / \mathrm{L}$ & $\leq 30$ \\
\hline Total Organic Carbon (TOC) & $\mathrm{mg} / \mathrm{L}$ & $<3$ \\
\hline Turbidity & $\mathrm{NTU}$ & $<1.0$ \\
\hline
\end{tabular}

Seawater sampling and analysis were carried out. All samples were taken on May $16^{\text {th }}, 2018$. The locations where samples were taken can be seen in Figure 8. The results of seawater analysis as follow (Table 4):

Table 4. The results of seawater analysis in the study area. Red colour indicates related parameters values exceed the recommended threshold.

\begin{tabular}{|l|l|r|r|r|r|l|}
\hline \multirow{2}{*}{ Parameter } & \multirow{2}{*}{ Unit } & \multicolumn{5}{|c|}{ Results - Sample (S) } \\
\cline { 3 - 7 } & & \multicolumn{1}{c|}{ S1 } & \multicolumn{1}{c|}{ S2 } & \multicolumn{1}{c|}{ S3 } & \multicolumn{1}{c|}{ S4 } & \multicolumn{1}{c|}{ S5 } \\
\hline $\mathrm{Al}^{3+}$ & $\mathrm{mg} / \mathrm{L}$ & 0.3 & 0.31 & 0.3 & 0.3 & 0.3 \\
\hline $\mathrm{Fe}$ & $\mathrm{mg} / \mathrm{L}$ & $<0.06$ & $<0.06$ & $<0.06$ & $<0.06$ & $<0.06$ \\
\hline $\mathrm{Mn}^{2+}$ & $\mathrm{mg} / \mathrm{L}$ & $<0.01$ & $<0.01$ & $<0.01$ & $<0.01$ & $<0.01$ \\
\hline $\mathrm{pH}$ Value & - & 7.94 & 8.08 & 8.13 & 8.15 & 8.14 \\
\hline $\mathrm{Sr}^{2+}$ & $\mathrm{mg} / \mathrm{L}$ & $<0.01$ & $<0.01$ & $<0.01$ & $<0.01$ & $<0.01$ \\
\hline $\mathrm{TDS}$ & $\mathrm{mg} / \mathrm{L}$ & 38244 & 38773 & 40222 & 38444 & 39962 \\
\hline $\mathrm{Temperature}$ & ${ }^{\circ} \mathrm{C}$ & 29.5 & 30 & 30 & 30 & 30 \\
\hline $\mathrm{TOC}$ & $\mathrm{mg} / \mathrm{L}$ & $<0.67$ & $<0.67$ & $<0.67$ & $<0.67$ & $<0.67$ \\
\hline $\mathrm{TSS}$ & $\mathrm{mg} / \mathrm{L}$ & 15 & 16 & 38 & 15 & 15 \\
\hline Turbidity & $\mathrm{NTU}$ & $<0.5$ & $<0.5$ & 0.78 & $<0.5$ & $<0.5$ \\
\hline
\end{tabular}

From Table 4 above, there are some parameters whose values exceed the recommended threshold to minimise the possibility of membrane damages (shown in red colour in the table). Some of the parameters are $\mathrm{Al}^{3+}$, Total Dissolved Solids (TDS), and Total Suspended Solids (TSS).

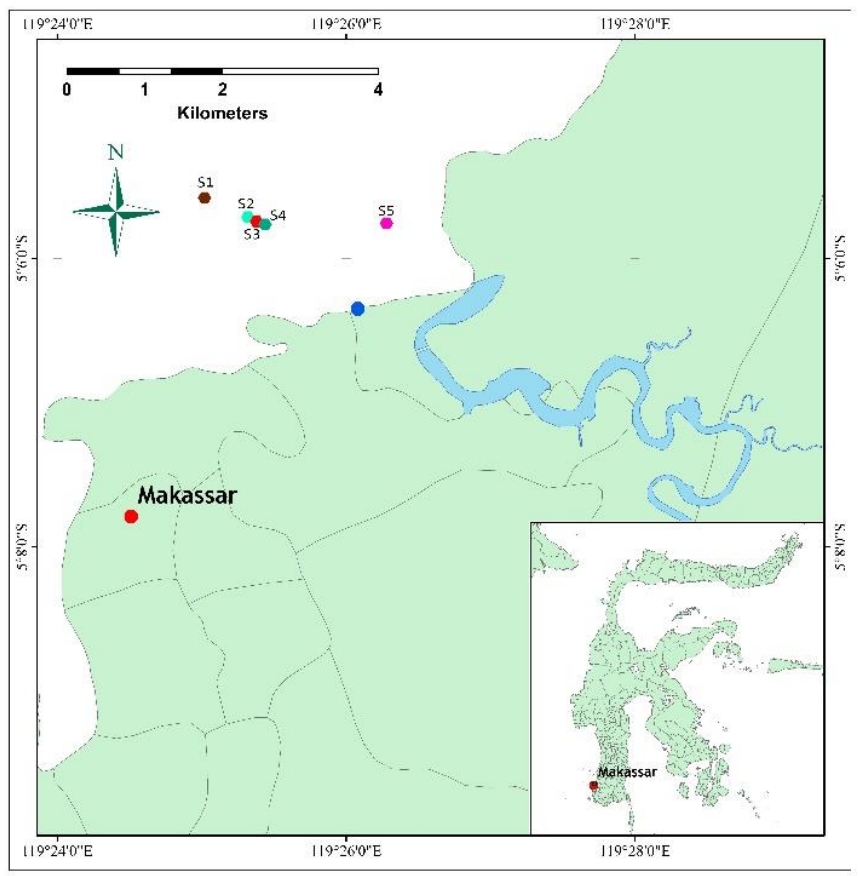

Fig. 8. The locations of seawater sampling. 
Seawater in the study area has a very high $\mathrm{Al}^{3+}$ value $(0.3 \mathrm{mg} / \mathrm{L})$ compared to the recommended $\mathrm{Al}^{3+}$ threshold value, which is $0.05 \mathrm{mg} / \mathrm{L}$. This condition will increase the likelihood of colloidal fouling on the membrane. Colloidal fouling occurs due to the concentration of particles such as $\mathrm{Al}^{3+}$, silica, and high clays which react with oxygen to form non-soluble oxides [17].

Furthermore, $\mathrm{Al}^{3+}$ also tends to form organic colloids and can deposit on the surface of the membrane and potentially clog membrane pores [17]. It will disrupt membrane function and reduce the amount of feed water that can enter the membrane.

One of five seawater samples taken in the study area also has high TDS and TSS values. These conditions also have the potential to cause colloidal fouling on the membrane.

\subsection{Seawater Intake}

In determining the location of seawater intake, several factors are considered. These factors are hydrooceanography (bathymetry, tides, and ocean currents), the distance between water intake point and pre-treatment facility, and the development plan of MN Port.

Based on bathymetry analysis that has been conducted, the study area is generally shallow water areas with the depth of seawater in the area ranging from 2-10 meters. Depths between 2-6 meters are found in the northern part of the port, while the depths at the western and southern of the ports are between 6-10 meters and 2-10 meters respectively.

Bathymetry analysis is vital to determine the depth of the intake pump. The intake pump should not be placed in shallow water areas as it can disrupt the water supply processes. On the other hand, the placement of the intake pump that is too close to seabed also has a risk of sediment entry.

Tides are also analysed to determine the ideal position of the intake pump. The study area is generally dominated by diurnal tides. Based on tide fluctuations from August 2018 forecast (Figure 4), the heights of the water are 1.25 meters (LAT) and 0.5 meters (MSL) (high tides), while when low tides, the heights of the water are 0.35 meters (LAT) and -0.5 meters (MSL).

The intake pump is recommended to be placed in sufficient depth. Thus, when low tide, the intake pump is still in the water, and the pump can still operate.

Besides the depth factor, the location of the intake pump is also considered. Intake pump should be placed in areas that are free from interference, whether it is interference from human activities or others.

Based on the port development plan, the north and northeast areas are areas that will not be developed in the future. From the field survey that has been conducted, these areas are also relatively free from fishing activities. However, these areas are directly connected to Tallo river estuary (Figure 1). The intake pump should be placed far from the river. Thus, it is not too affected by sediment supply from Tallo river.

The impacts of sedimentation from Tallo River can also be predicted by analysing ocean currents at the study area. In the north and northeast of the port, ocean currents generally have very low speeds ranging from 0.01-0.04 $\mathrm{m} / \mathrm{s}$ with the dominant direction to the west and then turn to the northeast. Therefore, sedimentation from Tallo river, which is about 1.5 kilometres from the port, is predicted does not have significant impacts.

SWRO facilities are planned to be built at the pump house. Water intake point that is near the pump house will have an impact on relatively smaller SWRO costs, due to the shorter pipes used. Short pipeline network will also impact on simpler maintenance aspects.

Based on the development plant of MN Port [2] [3], areas in the north and northeast of the port are free areas. On the other hand, the west zone is a designated area for loading and unloading ships. Moreover, in the southern part of the port, supporting facilities are planned to be built, such as container yards, green areas and railway lines.

After considering several factors: bathymetry, tides, currents, the distance between water intake point and the pump house, and the development plan of MN Port, water intake point should be in the north or northeast area of the port. Furthermore, the depth of the intake pump is recommended to be at around 2 meters from the seabed.

The distance between the pump house and the intake pump is around 250 meters (Figure 9) (Figure 10). The recommended intake pipe size is 8 -inch in diameter for SWRO with the capacity of $500 \times 2 \mathrm{~m}^{3} / \mathrm{d}$.

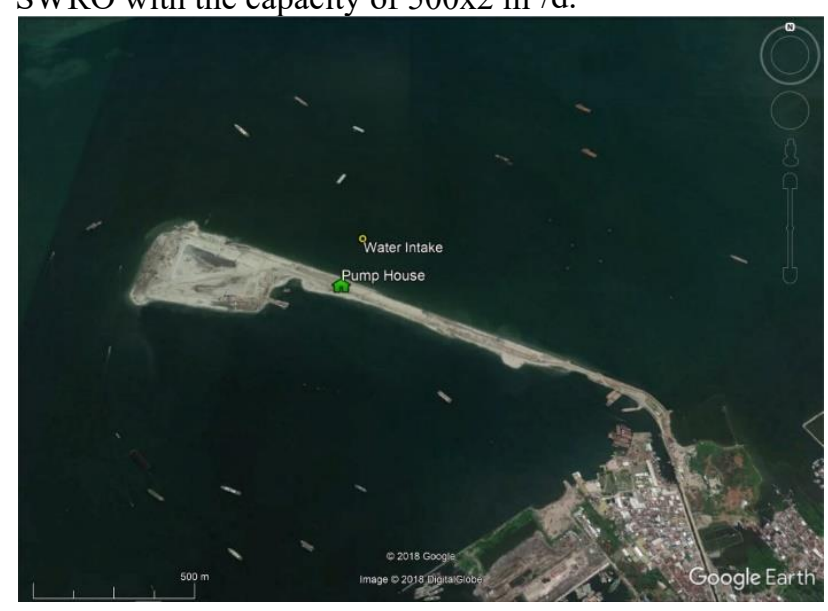

Fig. 9. The location of the water intake point (yellow dot). The distance between the water intake point to the pump house is approximately 250 meters.

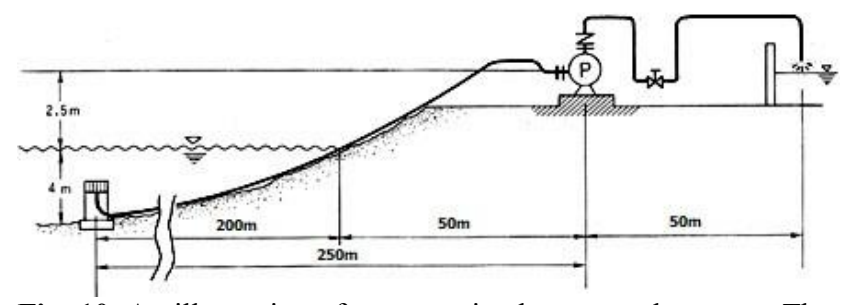

Fig. 10. An illustration of seawater intake pump placement. The pump is placed 2 meters from the seabed and 250 meters from the pump house. Modified from [18].

\subsection{Layout Plant}

Design for SWRO plant at MN Port consist of Clarifier which has a function to eliminate solids in feed 
water (Figure 11). It is crucial considering sea water in the study area has high TDS and TSS values.

Other components in SWRO plant design are (Figure 11):

- Plant water transfer pump

- Buffer tank

- Backwash pump
- Filtered seawater tank

- Permeate water tank

- Multimedia filter

- SWRO system

- CIP tank

- $\quad$ Filtered feed pump

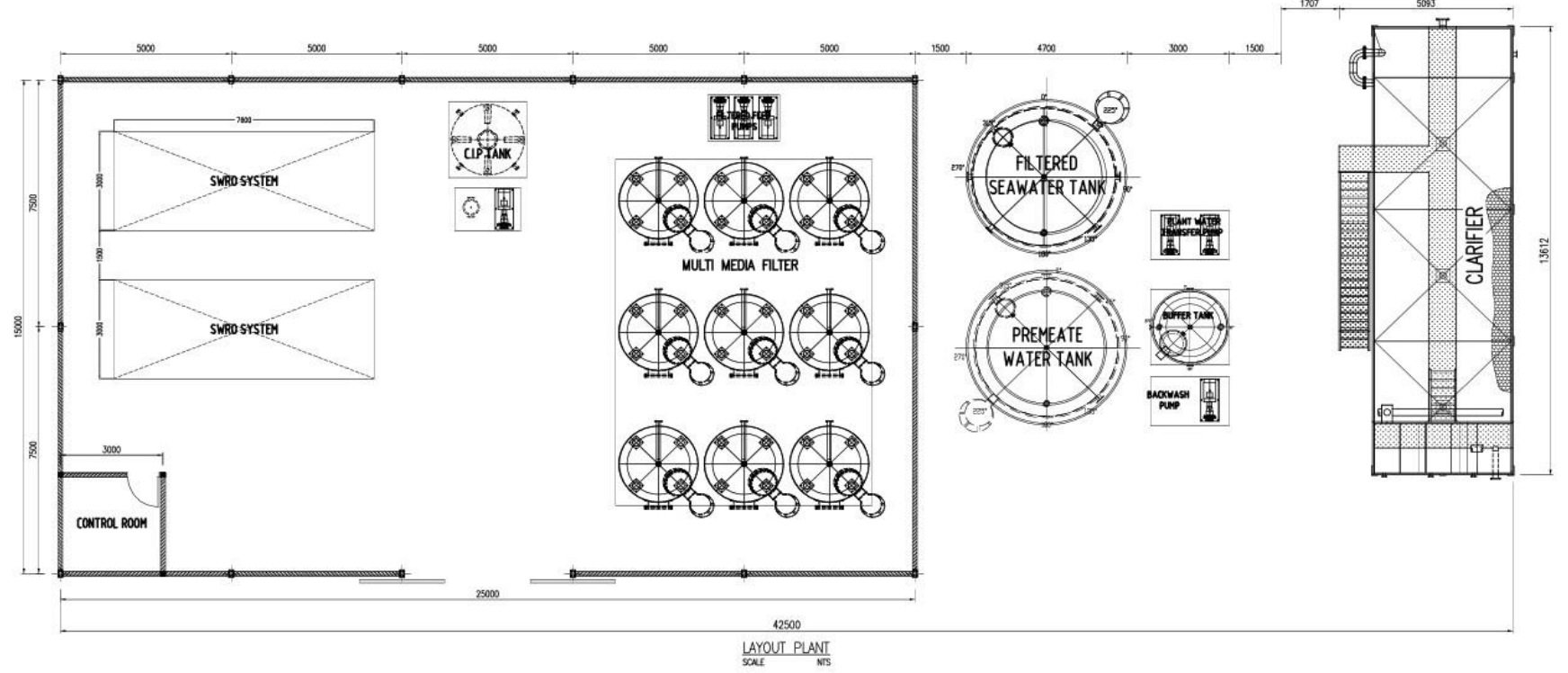

Fig. 11. Layout plant for SWRO with a capacity of $500 \times 2 \mathrm{~m}^{3} / \mathrm{d}$.

\section{Conclusion}

Based on the hydro-oceanography analysis, it can be concluded that reverse osmosis can be applied at MN Port. Water intake point is recommended to be placed at the north of the port. The distance between water intake point to pump house is around 250 meters.

Seawater quality analysis shows that several parameters exceed the recommended threshold values, such as $\mathrm{Al}^{3+}$, Total Dissolved Solids (TDS), and Total Suspended Solids (TSS). Therefore, the pre-treatment process is vital to minimise the likelihood of membrane fouling.

\section{References}

1. Indonesian Ministry of Marine Affairs and Fisheries, “Oceanography Data," 2017.

2. Indonesian Navy Hydrographic and Oceanographic Centre, "Data Hidrografi dan Oseanografi," pp. 1-10, 2018.

3. J. I. Pariwono, "Kondisi Pasang Surut di Indonesia." Lembaga Ilmu Pengetahuan Indonesia, Pusat Penelitian dan Pengembangan Oseanologi, Jakarta, 1989.

4. Siemens, "Optimization of Reverse Osmosis Seawater Desalination Plants by Advanced Process Control," 2016.
5. Puretec Industrial Water, "What is Reverse Osmosis?," 2012. [Online]. Available: https://puretecwater.com/reverse-osmosis/what-isreverse-osmosis\%0A. [Accessed: 28-Feb-2018].

6. N. Voutchkov, "Introduction to Reverse Osmosis Desalination," Middle East, no. January 2010, 2010.

7. N. I. Said, "Pengolahan Payau Menjadi Air Minum dengan Teknologi Reverse Osmosis," Teknol. Pengolah. Air Minum, pp. 443-501, 2008.

8. M. J. Guirguis, "Energy Recovery Devices In Seawater Reverse Osmosis Desalination Plants With Emphasis on Efficiency and Economical Analysis of Isobaric versus Centrifugal Devices,” p. 123, 2011.

9. J. Harris, "Basics of Reverse Osmosis," pp. 1-14, 2012.

10. R. Bharadwaj, D. Singh, and A. Mahapatra, "Seawater desalination technologies," Int. J. Nucl. Desalin., vol. 3, no. 2, p. 151, 2008.

11. N. Dhakal, "Controlling Biofouling in Seawater Reverse Osmosis Membrane Systems," Delft, the Netherlands, 2017.

12. A. Sagle and B. Freeman, "Fundamentals of Membranes for Water Treatment," Futur. Desalin. Texas, pp. 1-17, 2004.

13. R. Valavala, J. Sohn, J. Han, N. Her, and Y. Yoon, "Pretreatment in Reverse Osmosis Seawater Desalination: A Short Review," Environ. Eng. Res., vol. 16, no. 4, pp. 205-212, 2011. 
14. Mak Water, "Product Overview Sea Water Reverse Osmosis (SWRO)," 2013.

15. Applied Membranes Inc., "Feed Water Quality for Reverse Osmosis Systems," 2007. [Online]. Available:

http://www.watertreatmentguide.com/feed_water_qu ality.htm. [Accessed: 29-Aug-2018].
16. B. K. Shrivastava, "Efficient Management of Reverse Osmosis System in Water Treatment Plant," vol. 7, no. 3, pp. 2047-2055, 2009.

17. Microdyn-Nadir, "Feed Water Parameters Assessing RO \& NF Feed Water Quality,” 2017.

18. Yokota, "Resolving the Concerns of Seawater Pumping." [Online]. Available: http://www.aquadevice.com/english/01 top_topic08.ht m. 